\title{
CHINESE LANGUAGE LEARNING IN ASIA AND THE ETHNIC IDENTITY OF THE CHINESE POSTERITY
}

\author{
Yutaka Otsuka \\ Fukuyama University, Japan \\ email: F10384@fkuyama-u.ac.ip
}

\begin{abstract}
This paper firstly overviews the historical changes of Chinese language and its education in four nations of Southeast Asia. These nations experienced the blank period when Chinese language was oppressed or forbidden to use by the ruler at the time, although length and austerity of the blank period differs from nation to nation. However, according as their relationship with People's Republic of China in the international political arena has improved and economic exchanges have been vitalized, a different scene from previous era can be observed in the attitude towards overseas Chinese and their language. Questionnaire surveys were carried out for several years to make clear how the situation of Chinese language education looks like. Statistical analysis of the responses by nation and the comparison of responses from Chinese and non-Chinese youngsters leads us to some findings of how different conditions of each country give influence to the way Chinese language education is carried out and the consciousness and ethnic identity through language is being formed Keywords: chinese language, language learning, ethnic identitiy, chinese posterity.
\end{abstract}

\section{INTRODUCTION}

English is the principal language of international communication and will continue to maintain that position; however, major world powers are asserting the status of their own native languages and are striving to maintain and disseminate them in the globalizing world. Use of the Chinese language has also been conspicuously increased recently, as if to challenge the hegemony or overconcentration of English. As for the number of Internet users by language in the world, the Chinese language accounted for $21.5 \%$, which ranked second to the $26.0 \%$ of English, as of mid2015. Internet users who communicate in Chinese increased 2,080.9\% from 2000 to 2015 (Internet World Stats, 2019, p.1). There is also statistical evidence that the Chinese language has already exceeded English in terms of the distribution of principal languages in the world population
(Huntington, 2000, p. 95). Thus, the significance of the Chinese language as an international language is not small.

A proverb says, "There are ethnic Chinese wherever there is sea water, and Chinese language education is indispensable wherever there are ethnic Chinese (Weineng \& Xiaohong, 2003). Southeast Asia is a place where overseas Chinese (華僑) and ethnic Chinese (華人) lived the earliest and most populously, and the education of Chinese as their ethnic language has continued in spite of it being full of twists and turns. In addition, the Chinese government has been positively driving forward the international spread of their own language and its external education policy as represented by the worldwide deployment of the Confucius Institutes. Many topics deserving pedagogical analysis and scrutiny are contained in many of the phenomena and undertakings of China's 
language dissemination policy, for example, how teachers in charge are prepared and trained, how the cost of teaching materials and other necessary expenses are covered, and what cultural influence and ideological elements are contained within the teaching materials.

To examine the many topics concerned with overseas Chinese and ethnic Chinese, there are special research institutions such as the Overseas Chinese Research Center of Takushoku University in Japan. Research institutes at Jinan University, Huaqiao University in southern China, and Jinan International University in Taiwan specializing in the issues of overseas Chinese and ethnic Chinese have been actively accumulating research results including a plethora of historical studies.

Among these studies, issues of Chinese language education in various places are also included. However, there are only a few fieldwork-based studies that have clarified the situation from the viewpoint of the consciousness of children who learn the Chinese language. In particular, there are almost none that compare and contrast the situation from the viewpoint of Chinese posterity in genealogy (華裔) and nonChinese posterity with regard to country of residence within several Asian nations, over the forty years that I have surveyed the subject. Therefore, this paper, depending on previous studies from the above-mentioned specialized research institutions and others, first roughly discusses changes in the Chinese language and its education in four nations in Southeast Asia, i.e., Cambodia, Thailand, Indonesia and Vietnam, from a viewpoint of identity formation of the ethnic Chinese people through their own language, and the Chinese government's policy on external language education toward outside countries. Then, some knowledge acquired from a series of questionnaire surveys of students concerning Chinese language education which have been carried out over the past five years in each country will be presented.

Although the start of movement of people between Cambodia and China dates back to as early as the Tang dynasty, Chinese who immigrated to Cambodia increased during the period of governance by France, which began in 1863 and a Chinese society within Cambodia was gradually (Yu-e, 1995, p. 373) formed. The colonial government took the "Bang Office" (墔公所), or consolidated benevolent association system, as a policy for overseas Chinese. A “bang (素守)” is a benevolent organization in which those from the same province and of the same family origin or those engaged in the same trade organize themselves and cooperate with each other. It is an expanded form of a guild. These bangs impose a duty of subscription to any guild or clique. This cooperation is primarily related to economic activities, and, even in foreign lands, this system is maintained. As a result, halls for bangs associated with Chaozhou(潮州), Guangdong (広肇), Fujian (福建), Hainan (海南), and Hakka (客属) were established. In 1914 the Chaozhou Bang founded its Duanhua (端華) School in Phnom Penh, other bangs followed and built their own schools as if to assert their identity. Schools associated with five bangs existed in the early 1930s: the Minsheng School of Fujian Bang, the Guangjihui School of Guangdong Bang, the Jicheng School of Hainan Bang, and the Chongzheng School of Hakka Bang.

Since the 1950s, many overseas Chinese acquired Cambodian nationality, and became the ethnic Chinese of Cambodia. Many Chinese schools were developed from the 1950s to the 1960s with more than 200 schools existing in the country and over 50,000 children enrolled in elementary 
and junior high schools at that time. Fifty schools existed in Phnom Penh. Among them the Duanhua School was the largest with as many as 4,500 students enrolled. Although many schools were elementary school level and junior high school level, education of the high school level was also provided in both the Duanhua School and the Minsheng School in Phnom Penh, at the Guoguang School in Battam Bang, and also at the Zhongshan School in Kratie (Yu-e, 1995, p. 374).

However, the administration of President Lon Nol oppressed overseas Chinese and ethnic Chinese in 1970. Use of the Chinese language and its education was totally prohibited, and Chinese language schools were forced to close. Overseas Chinese were again the target of a 'cleanup' or persecution campaign during the era of the ultra-left Khmer Rouge government from 1975 to 1979 . The population of overseas Chinese and also of the ethnic Chinese decreased until the beginning of the 1980's due to their evacuation from the country during the Vietnamese inroads.

However, with the arrival of a relatively peaceful time, overseas Chinese and ethnic Chinese experienced a phoenix like revival with the population consistently increasing. In 2015, the population of overseas Chinese and ethnic Chinese was 223,300 and accounted for $1.4 \%$ of the total population 15,864,000 (Joshua Project, n.d). Meanwhile, since the end of 1990s, Chinese language education has been recovering. In October, 1991, the Qihua (啓華) School in Kompong Cham Province resumed lessons. These came about, in part, through the efforts of Mr. Chen Shu (陳薯), who developed school infrastructure.

It became impossible to satisfy people's needs with small-scale private supplementary classes; therefore, the
Zhongyang (中央) School, the Polongbian (坡隆辺) School, the Lipo (立坡) School, the Shalina (莎麗娜) School, the Huaqun (華群) School, and the Peiwen (培文) School opened successively in Phnom Penh from 1991 to 1992 . Outside of Phnom Penh, the Lianhua (聯華) School in Battambang Province, the Juequn (覚群) School in Kam-pot Province, and the Zhongshan (中山) School in Kratie Province. also resumed classes. The Chinese government has been promoting positive support of Chinese language education through the Association of Khmer Chinese in the Kingdom of Cambodia (柬華理事総会), which is a benevolent organization among overseas Chinese and ethnic Chinese in Cambodia. However, it cannot be said that Chinese language education was necessarily sailing large before the wind. This is due to the influence of the Asian economic crisis that happened subsequently. Each Chinese Language school is making its own efforts in carrying out the bilingual education of Chinese and Khmer or trilingual education with the inclusion of English.

It is said that approximately 7 million ethnic Chinese, who account for a little more than $10 \%$ of the total population, were in Thailand as of 2007. According to another statistic, it is also said that the number is less than 1.6 million. Because the Thai government does not openly provide demographic statistics by ethnic group, estimated values differ greatly. Most of the ethnic Chinese in Thailand used to be labour immigrants, who came from the southern China area after the 19th century, as well as their descendants. Statistics by hometown indicate that these Chinese are overwhelmingly from Chaozhou. Their "native languages" are the Chaozhou dialect and the Fujian language. It was in the 1920's, after the establishment of the Republic of China, that the so-called 
"Chinese language (standard Chinese)" spread in the ethnic Chinese society as a common language.

Influenced by the upsurge of nationalism in mainland China and the spread of standard Chinese, a common identity as "Chinese" beyond the bang was born among the Thai ethnic Chinese. On the other hand, Thai nationalism rose through the constitutional revolution of 1932 in Thailand and it was antagonistic to the nationalism of the ethnic Chinese. The fact that "the Four Books and the Five Classics" were taught to children in private classes built by the ethnic Chinese in Thailand after the $14^{\text {th }}$ century is known. Moving our focus to the 20th century, until the shift to the constitutional monarchy in 1932, each bang founded many of their own schools, such as Xinmin Xuetang ( 新民学堂), Datong Xuetang (大同学堂 , later renamed as Nanying Xuetang 南英学 ), the Honghua (宏華) School, the Yucai ( 育才) School, the Jinde (進徳) School, the Mingde (明徳) School, the Peiyuan ( 培元) School, and the Peiying (培英) School under a permissive attitude toward Chinese language education of the Thai government.

The Private School Law enacted in 1918 by King Rama VI and the Compulsory Education Enforcement Ordinance in 1921 were not executed very strictly at first. However, after shifting to the constitutional monarchy in 1932, the situation changed, and a tightening of the rules progressed. The class hours per week for the Chinese language were limited to less than six hours, and the use of textbooks including political contents was forbidden. In the period from 1933 to 1935 , about 300 Chinese language schools closed.

Despite facing difficulties, during the period dating from 1932 to 1939 Chinese language education in Thailand still continued to develop. Because the severe Chinese language education policy led to the dissatisfaction of many overseas Chinese and ethnic Chinese who grasped economic strength and exercised a negative influence on the Thai economy, the Thai government could not help but revise the policy. The Nationalist Government of China, on the other hand, offered support to Chinese language schools. However, when Luang Pibulsonggram took the post of prime minister in 1938, he executed an exhaustive control against Chinese language education under his pro-Japan and anti-China policy. Chinese language education experienced the greatest period of challenge in its history in Thailand and all 294 Chinese language schools which existed at that time disappeared (Murata, 2007, p. 164-172).

After World War II, Chinese language schools were resurrected for a brief period from 1945 to 1948 . However, after the founding of the People's Republic of China in 1949, Thailand, which occupied one corner of an anticommunist camp, forced Chinese language education to adhere to a myriad of controls and limitations (Hiizumi, 1987, p. 129-130; Murata, 2007, p. 174176), that is, the class hours for Chinese language study were restricted, and actions to close the schools were taken up again. Such severe control was mitigated in 1992 by a decision by the Cabinet led by Prime Minister, Anand Panyarachun, to end the long period of limits (Suzuki, 1995, p. 88-89).

Moreover, when formal talks between the Thai Minister of Education, Chaturon Chaisangon, and China's Vice Minister of Education, Zhang Xinsheng, were held on January 11, 2006 and were followed by an agreement of support for Chinese education in Thailand, hospitable assistance by China started. The assistance included the dispatch 
of Chinese language education volunteer teachers from China, the training of Thai teachers specializing in Chinese language education, and the establishment of the Confucius Institute, which is overseen by the Confucius Institute Headquarters (hereafter "Hanban"). The Thai Ministry of Education founded Chinese language educational centers in 20 locations all over the country in 2007 to attain the standardization of teaching methods and curricula. It also decided to establish a Chinese language teacher training course. However, such actions do not aim to teach the Chinese language as an ethnic language to ethnic Chinese people (Tamaki, 2007), but it is consistently maintained that the purpose is to teach the Chinese language as a foreign language just as other languages such as English and Japanese are taught. In celebrating the 35 th anniversary of the normalization of diplomatic relations between the two countries in 2010, a further boom in Chinese language education appeared in Thailand.

Today, the population of overseas Chinese and ethnic Chinese in Indonesia reaches about 7,400,000 and accounts for $3.5 \%$ of the total population and constitutes the greatest ethnic minority in the country (Yannan, 2005). The history of Chinese language education in Indonesia can be traced back to 1690 when Mingcheng Shuyan (明誠書院), a private academy, was opened by overseas Chinese in Batavia (present Jakarta). Then, the traditional private academies with Chinese language as a medium of instruction were built in various places. The Four-Books and Five Classics were taught at those academies, which were opened by the overseas Chinese merchants from Fujian or Guangdong provinces, and teachers also taught in the Fujian dialect or in Cantonese.
In the 20th century, overseas Chinese founded the Chinese School Attached to Batavia Chinese Hall (中華会館中華学校) on March 17, 1901, which was a forerunner of modern schools. Subsequently, the Chinese General Assembly (中華総会) was established in 1906 and it was renamed as the Java School Affairs General Assembly (爪哇学務総会). It functioned as an organization to control Chinese language education in the whole country. Unlike the above-mentioned private academies, modern schools came to teach modern subjects such as arithmetic, geography, English, and gymnastics in addition to Chinese language and history.

The media of instruction was neither the Fujian dialect nor Cantonese any longer but was changed to the "national language", "Mandarin", the standard Chinese based on the Beijing dialect. However, Chinese language education soon declined under the suppression dictated by the Dutch colonial government as well as during the war. The ethnic Chinese people were suppressed during the Japanese war-time administration for three and a half years. After World War II, Chinese language education temporarily showed a sign of prospering again under a relatively tolerant policy over Chinese language education by the new government after the independence. Chinese language schools in Indonesia numbered about 200, with 425,000 students enrolled in 1957 (Yu-e \& Lei, n.d). However, the Sukarno Administration gradually expressed concern over too great of a proliferation of Chinese language education and eventually came to add various kinds of restrictions. That is, a new Chinese language school was forbidden to be established, students with Indonesian nationality were prohibited from attending any Chinese language school, and the zone to build a Chinese language school was restricted. This intensified when the 
Sukarno Administration collapsed with the September 30, 1965 coup détat led by Suharto. Chinese language education faced a much more serious situation under President Suharto, who assumed power. Suharto thoroughly executed an assimilation policy for ethic Chinese in Indonesia, he forbade the use of the Chinese language, and closed down Chinese language schools. In this way, the Chinese language and its education was oppressed and forbidden for more than 30 years.

However, as Indonesia's relations with mainland China improved in the realm of international politics and economic exchanges, an unprecedented change arose with the ethnic Chinese and their native language. The previous policy forbidding the use of Chinese language was reviewed. Furthermore, an understanding of the Chinese language and a tolerant policy have been further strengthened under the administrations of Presidents Wahid, Megawati, and Yudhoyono. Plans to vigorously promote Chinese language education were adopted, and the Chinese language came to be learned as one of the foreign language subjects.

From the end of 2000 to the beginning of 2001, the Indonesian Ministry of Education in cooperation with the Chinese Ministry of Education as well as the Cultural Affairs Department of the Chinese Embassy in Indonesia tried to enforce bilateral relations involving Chinese language education. These efforts included, for example, setting up a special section in the Ministry to advance the unification of teaching materials, letting the Chinese language educational adviser dispatched from China stay regularly within the Ministry of Education, and taking a series of measures for the implementation of HSK examinations (Guwen, 2001; Otsuka, 2015, p. 49-65).
Ethnic Chinese is one of the 54 ethnic groups constituting the Vietnamese people. According to an existing statistic, as of 2015, the population of ethnic Chinese was $1,891,000$, which is about $2.0 \%$ of the total population of 84 million (Saigon Liberation Daily, 2010). It is said that around half reside in Ho Chi Minh City. As for Chinese language education, it is common to distinguish Hua Yu (華語) from $\mathrm{Han} \mathrm{Yu}$ (漢語). The former is to maintain and accede the ethnic Chinese people's language and culture as one of the ethnic minorities, while the latter is to be taught as a foreign language. Chinese language education, known as Hua Yu education, is conducted mainly in the 5th division (Cho Lon area), as well as the 6th and the 11th divisions where the ethnic Chinese people are concentrated in Ho Chi Minh City. From a nationwide perspective, Chinese language education is also carried out in some southern provinces, such as Binh Duong, Dong Nai, and Can Tho in addition to Ho Chi Minh City.

China and Vietnam, two countries sharing a border, have been intercommunicating since ancient times. Historical records state that the ethnic Chinese came to reside permanently in Vietnam in excess of 1000 years, and especially from the end of the Ming Dynasty to the beginning of the Qing Dynasty in the 17 th century. The surviving retainers of Ming moved to Vietnam in droves. From the end of the 19th century end to the beginning of the 20th century, under the French colony, Saigon (present Ho Chi Minh City) attracted many overseas Chinese as a large trade base in Southeast Asia. Then, during the separation of north and south for 20 years from 1954, the ethnic Chinese people substantially controlled the business community, and they established strong roots in Vietnamese society. 
However, after the north-south unification in 1975, the ethnic Chinese who feared oppression under communism fled the country. Also, the number of ethnic Chinese who went abroad increased before and after the China-Vietnam War in 1979 which broke out due to a confrontation between two communist parties. Under such extraordinary circumstances between the two countries, the influence of the ethnic Chinese in Vietnam declined extremely, and so too did Chinese language education. Both Hua Yu and Han Yu education were substantially interrupted or stagnated for 10 years from the beginning of the 80s until around 1992.

However, in 1986 as the Vietnamese government introduced the "doi moi" policy, which was a move away from a planned economy to a market economy, it actively pursued economic and cultural exchanges with other nations. The personal connections of the ethnic Chinese played a significant role in introducing foreign capital and technology. Investors using the Chinese language from areas such as Taiwan, Hong Kong, and Singapore became the main force for the introduction of foreign capital to Vietnam. In this context, a warming of relations appeared between China and Vietnam from the late 1990s. The demand for Chinese language as a foreign language as well as an ethnic minority's native language increased gradually, and various kinds of educational activities came to be developed (Otsuka, 2008, p. 127-145). It was overseas Chinese and ethnic Chinese that substantially supported such movement.

Each country has thus far experienced various deployments of Chinese language education. In order to clarify what kind of attitudes pupils and students of elementary and secondary schools have toward Chinese language education after such changes, therefore the questionnaire surveys was need in that four nations.

\section{METHOD}

This research took place in four nations (Cambodia, Indonesia, Thailand. and Vietnam) for a few years beginning in 2014. Questionnaires were prepared both in Chinese and in the language of each respective country, with the help of teachers in charge in each classroom and we received some support from locals in each country (Otsuka, 2008, p. 127-145).

We chose the following schools and areas as targets of our questionnaire survey, since some countries have not long carried out Chinese language education and have not necessarily carried it out throughout the country. That is, schools run by ethnic Chinese which have adopted the Chinese language as the medium of instruction, or areas where relatively numerous ethnic Chinese residents live and and Chinese language is adopted as a part of teaching subjects were chosen.

Since the Chinese language is not widely taught at ordinary schools in Cambodia, two schools named Duan Hua and Li Qun were chosen. They are run by ethnic Chinese and they are proud of their long history, and almost all of their registered students are children of ethnic Chinese. Since the Chinese language is studied as a foreign language in Indonesia, ten ordinary elementary and secondary schools of the cities Semarang, Salatiga, and Surabaya, where ethnic Chinese are relatively concentrated, were chosen as survey targets.

In Thailand, as was mentioned previously, the Chinese language is studied as a foreign language along with English and Japanese; however, schools with a comparatively large enrollment of ethnic Chinese children such as the Guanjiao School and the Trymit School were chosen for the survey. In Vietnam, it was possible to investigate in Bac Lieu Province in the 
south and Lang Son Province and Hanoi City in the north, in addition to Ho Chi Minh City, where the ethnic Chinese residents are concentrated in the south, and thus quite a wide range of primary schools and junior and senior high schools all over the country were included.

The total number of respondents was 2,458 with a breakdown by country of: 631 in Cambodia, 367 in Thailand, 843 in Indonesia, and 617 in Vietnam. As for the respondent's qualitative attributes, 1,116 (45.5\%) were high school students. This group accounted for a little less than half of the 2,452 persons who included information about their own grade level. Additionally, there were 917 elementary school children $(37.4 \%)$ and 419 junior high school students (17.1\%). Thus, the sample is a little skewed toward the high school student group. Therefore, we decided to refrain from analyzing the data by kind of school, age, and grade. There were 1,005 males (41.3\%) and 1,427 females (58.7\%) among the 2,432 respondents who indicated their gender.

Questionnaire consists of eight questions covering about the question of respondent's ethnicity, frequency of using chinese language daily, learning of english or other foreign languages, length of Chinese language learning, interest and concern about Chinese language learning, difficulties in chinese language learning, the reasons to learn the Chinese language, and the wish for studying-abroad.

\section{RESEARCH RESULTS AND DISCUSSION}

In order to clarify what kind of attitudes pupils and students of elementary and secondary schools have toward Chinese language education after changed, it can be seen from the eight questions in this survey.

The respondent's ethnicity. With regard to the question of respondent's ethnicity, "whether you are posterity of overseas
Chinese or ethnic Chinese (華裔, hereafter described as Chinese posterity)," 66.7\% of the 2,416 respondents answered "yes". Table 1 presents data regarding reply to the question of respondent's ethnicity.

Seen by country, it shows that the percentage of people with either Chinese posterity or Chinese ethnicity is the highest in Cambodia and ranges through to the lowest percentage, which is in Vietnam. It is difficult to determine even a rough approximation of the percentage of the ethnic Chinese population with the available data, as the number varies from study to study as mentioned above.

That is, the lack of concrete population data makes it impossible to ascertain an accurate ratio of Chinese posterity existent to those surveyed in this research. However, because the estimated range is from only a few percent to about ten percent, the ratio of the ethnic Chinese population in this survey is very high in light of the factual composition ratio of each investigated country. Therefore, judging from the total number of ethnic Chinese in the parent population, respondents to this survey do not necessarily reflect the parent population. Incidentally, except for all target schools of this survey in Cambodia being ethnic Chinese schools, schools surveyed in the other three countries are a mixture of schools mainly taught in Chinese language and other ordinary schools where Chinese language is taught as a subject. On the other hand, even at the ethnic Chinese schools in Cambodia, non-ethnic Chinese children are also enrolled.

In the following analysis of the question responses, it is possible to better understand the impact of the influence of various conditions of each respective country and ethnicity situation on the state of Chinese language education through comparison of different countries and the difference 
Table 1

Reply to The Question of Respondent's Ethnicity $(\chi 2=299.604, d f=3, p<.001)$

\begin{tabular}{|c|c|c|c|c|c|}
\hline & & & \multicolumn{2}{|c|}{ Chinese Posterity } & \multirow{2}{*}{ Total } \\
\hline & & & Yes & No & \\
\hline \multirow[t]{15}{*}{ Country } & Cambodia & frequency & 549 & 64 & 613 \\
\hline & & $\%$ of country & $89.6 \%$ & $10.4 \%$ & $100.0 \%$ \\
\hline & & $\%$ of total & $22.7 \%$ & $2.6 \%$ & $25.4 \%$ \\
\hline & Thailand & frequency & 254 & 112 & 366 \\
\hline & & $\%$ of country & $69.4 \%$ & $30.6 \%$ & $100.0 \%$ \\
\hline & & $\%$ of total & $10.5 \%$ & $4.6 \%$ & $15.1 \%$ \\
\hline & Indonesia & frequency & 552 & 285 & 837 \\
\hline & & $\%$ of country & $65.9 \%$ & $34.1 \%$ & $100.0 \%$ \\
\hline & & $\%$ of total & $22.8 \%$ & $11.8 \%$ & $34.6 \%$ \\
\hline & Vietnam & frequency & 257 & 343 & 600 \\
\hline & & $\%$ of country & $42.8 \%$ & $57.2 \%$ & $100.0 \%$ \\
\hline & & $\%$ of total & $10.6 \%$ & $14.2 \%$ & $24.8 \%$ \\
\hline & Total & frequency & 1612 & 804 & 2416 \\
\hline & & $\%$ of country & $66.7 \%$ & $33.3 \%$ & $100.0 \%$ \\
\hline & & $\%$ of total & $66.7 \%$ & $33.3 \%$ & $100.0 \%$ \\
\hline
\end{tabular}

depending on whether the respondents are ethnic Chinese or not.

Frequency of using chinese language daily. In the question "Is there any person daily using Chinese language in your home or among your relatives?", there were more positive answers $(57.3 \%)$ than negative answers $(42.7 \%)$ as indicated in the total column of Table 2. Focusing on only Chinese posterity, it turns out that there is someone using the Chinese language on a daily basis in as many as three fourth of the respondents' homes as shown in the upper row of Table 2. It seems that the children of these Chinese posterities have more chances to touch Chinese language every day.

Table 2

The Difference of Frequency in Use of The Chinese Language between Ethnic Chinese and Non-ethnic Chinese $(\chi 2=655.477, d f=3, p<.001)$

\begin{tabular}{|c|c|c|c|c|c|}
\hline & & & Chinese & lome $* * *$ & Total \\
\hline & & & Yes & No & Iotai \\
\hline Chinese & Yes & frequency & 1210 & 387 & 1597 \\
\hline posterity or not & & $\%$ of Chinese posterity & $75.8 \%$ & $24.2 \%$ & $100.0 \%$ \\
\hline & & $\%$ of total & $50.5 \%$ & $16.1 \%$ & $66.6 \%$ \\
\hline & No & frequency & 164 & 636 & 800 \\
\hline & & $\%$ of Chinese posterity & $20.5 \%$ & $79.5 \%$ & $100.0 \%$ \\
\hline & & $\%$ of total & $6.8 \%$ & $26.5 \%$ & $33.4 \%$ \\
\hline & & frequency & 1374 & 1023 & 2397 \\
\hline Total & & $\%$ of Chinese posterity & $57.3 \%$ & $42.7 \%$ & $100.0 \%$ \\
\hline & & $\%$ of total & $57.3 \%$ & $42.7 \%$ & $100.0 \%$ \\
\hline
\end{tabular}


Checking by country, while as the highest with $69.2 \%$ answering in the affirmative was in Cambodia where nearly 90 percent of respondents are Chinese posterity, only a half of the ratio answered "yes" in Vietnam where $42.8 \%$ of respondents are Chinese posterity, as shown in Table 3.

Comparing the ratio of Chinese posterity and non-Chinese posterity with the frequency of use of Chinese language at home, the Chinese language usage ratio in Thailand is a little low and is still lower in Vietnam, while it is almost well-balanced in Indonesia. Even if taking the fact that the surveyed schools in Cambodia were Chinese language schools while those in Vietnam were ordinary schools into consideration, the degree of Chinese language used daily in the Vietnamese home is particularly low. This level of usage can be contrasted with Thai and Indonesian schools, which were the same as Vietnamese schools in that they were not limited to Chinese language schools.
Learning of english or other foreign languages. As a question to clarify the position of the Chinese language in the study of foreign languages, "Are you studying English in your school in addition to the Chinese language?" was asked. To this question, 2,156 students (88.9\%), who are the overwhelming majority of the total 2,422 respondents, answered that they are studying English, as shown in the total column of Table 4 .

Although the ratio of those who are not studying English is relatively high (22.4\%) in Cambodia, this is because the investigated schools were ethnic Chinese institutions. As mentioned above, the Chinese language schools in Cambodia which carry out the trilingual education in Khmer and English in addition to Chinese language as a policy to attract more students and to respond to increasing demands for English in recent years.

Following the question concerning English learning, a question, "whether another language (except for English) is

Table 3

How Often Chinese Language is Used at Home in each Contry? $(\chi 2=172.933, d f=3, p<.001)$

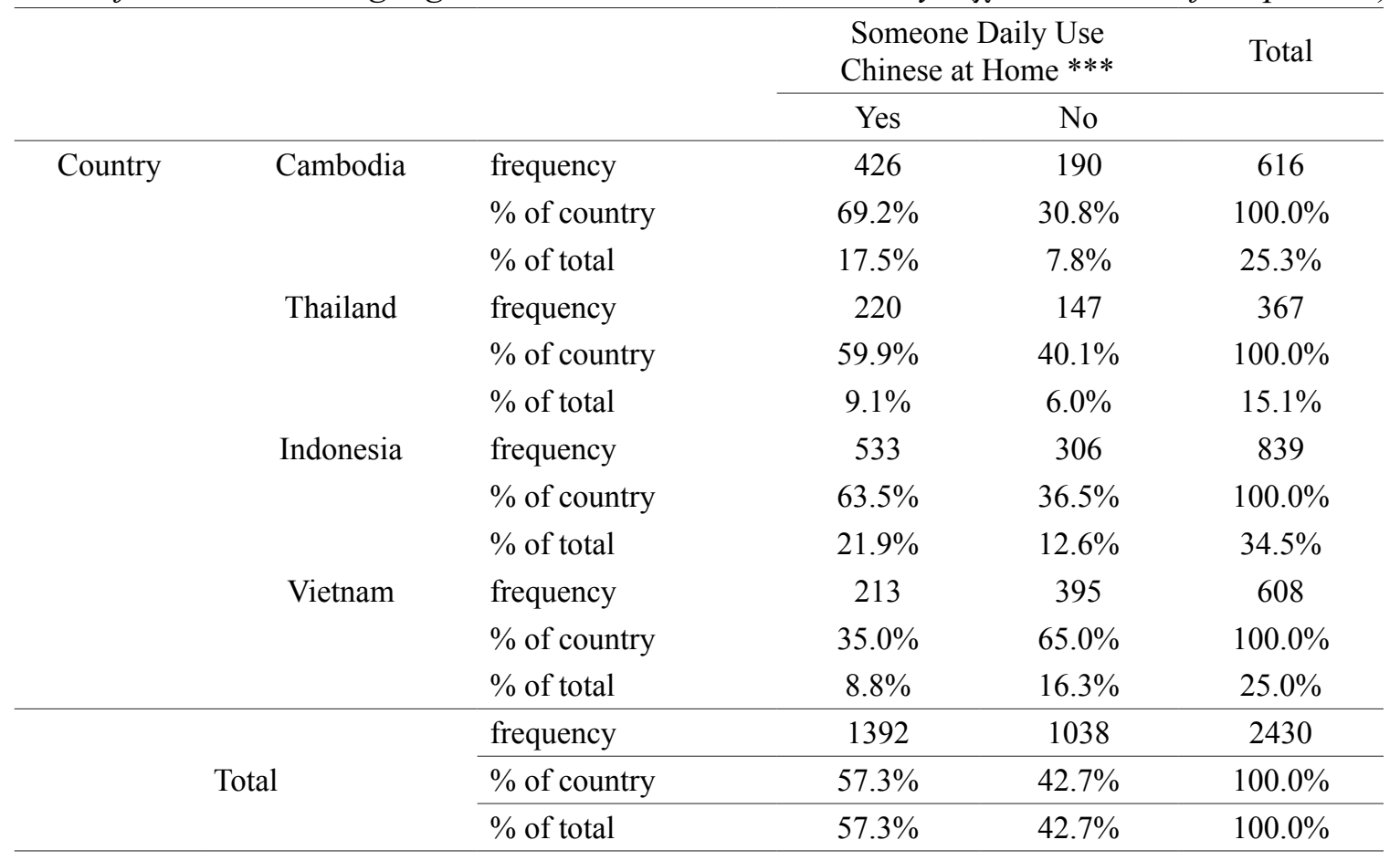


Table 4

\begin{tabular}{|c|c|c|c|c|c|}
\hline & & & \multicolumn{2}{|c|}{$\begin{array}{l}\text { Do You Learn English } \\
\text { in Your School? *** }\end{array}$} & \multirow{2}{*}{ Total } \\
\hline & & & Yes & No & \\
\hline \multirow[t]{15}{*}{ Country } & \multirow[t]{3}{*}{ Cambodia } & frequency & 475 & 137 & 612 \\
\hline & & $\%$ of country & $77.6 \%$ & $22.4 \%$ & $100.0 \%$ \\
\hline & & $\%$ of total & $19.6 \%$ & $5.7 \%$ & $25.2 \%$ \\
\hline & \multirow[t]{3}{*}{ Thailand } & frequency & 361 & 6 & 367 \\
\hline & & $\%$ of country & $98.4 \%$ & $1.6 \%$ & $100.0 \%$ \\
\hline & & $\%$ of total & $14.9 \%$ & $.2 \%$ & $15.1 \%$ \\
\hline & \multirow[t]{3}{*}{ Indonesia } & frequency & 823 & 18 & 841 \\
\hline & & $\%$ of country & $97.9 \%$ & $2.1 \%$ & $100.0 \%$ \\
\hline & & $\%$ of total & $34.0 \%$ & $.7 \%$ & $34.7 \%$ \\
\hline & \multirow[t]{3}{*}{ Vietnam } & frequency & 497 & 107 & 604 \\
\hline & & $\%$ of country & $82.3 \%$ & $17.7 \%$ & $100.0 \%$ \\
\hline & & $\%$ of total & $20.5 \%$ & $4-4 \%$ & $24.9 \%$ \\
\hline & \multirow{3}{*}{ Total } & frequency & 2156 & 268 & 2424 \\
\hline & & $\%$ of country & $88.9 \%$ & $11.1 \%$ & $100.0 \%$ \\
\hline & & $\%$ of total & $88.9 \%$ & $11.1 \%$ & $100.0 \%$ \\
\hline
\end{tabular}

studied in addition to Chinese language in your school" was asked. About three fourths of the total students answered "No." Particularly, $91.3 \%$ of Vietnamese students are not studying other languages as shown in the total column of Table 5.

Length of Chinese language learning. The distribution of all respondents to a question "How long have you been learning the Chinese language?" is shown in Table 6 . No less than $60 \%$ of 2,431 respondants. have been learning the Chinese language for more than three years. Looking at the result by country, the ratio of those who have learned the Chinese language for three years or more is as high as $94.9 \%$ in Cambodia. On the other hand, in Vietnam, the number who are learning for three years or more is $44.7 \%$, while $30.6 \%$ of students have just begun and have been learning for less than half a year.

Interest and concern about Chinese language learning. Although the length of learning varies from respondent to respondent, when they were asked whether Chinese language learning was "interesting", about $90 \%$, the overwhelming majority, answered that is was "interesting." As shown in Table 7, all respondents in Cambodia answered "interesting".

Difficulties in chinese language learning. When asked whether Chinese language learning is difficult, as shown in Table 8, those who answered "difficult" were a majority in each of the countries, but it is conspicuous that as many as 80 percent answered "difficult" in Thailand.

As for the difference between Chinese posterities and non-Chinese posterities, those who think "difficult" in the four countries account for $58.2 \%$ of ethnic Chinese and $65.7 \%$ of non-Chinese posterities. There are more students who feel difficulty among non-Chinese posterities, who do not inherit Chinese blood, and a statistically significant difference is seen in this result $(\chi 2=12.541$, $\mathrm{df}=3, \mathrm{p}<.001)$. 
Table 5

Whether another language (except for English) is Studied in Addition to Chinese Language in School? $(\chi 2=214.021, d f=3, p<.001)$

\begin{tabular}{|c|c|c|c|c|c|}
\hline & & & \multicolumn{2}{|c|}{$\begin{array}{l}\text { Learning of Another Language } \\
\text { Besides English *** }\end{array}$} & \multirow[t]{2}{*}{ Total } \\
\hline & & & Yes & No & \\
\hline \multirow[t]{15}{*}{ Country } & \multirow[t]{3}{*}{ Cambodia } & frequency & 161 & 448 & 609 \\
\hline & & $\%$ of country & $26.4 \%$ & $73.6 \%$ & $100.0 \%$ \\
\hline & & $\%$ of total & $6.6 \%$ & $18.5 \%$ & $25.1 \%$ \\
\hline & \multirow[t]{3}{*}{ Thailand } & frequency & 186 & 180 & 366 \\
\hline & & $\%$ of country & $50.8 \%$ & $49.2 \%$ & $100.0 \%$ \\
\hline & & $\%$ of total & $7.7 \%$ & $7.4 \%$ & $15.1 \%$ \\
\hline & \multirow[t]{3}{*}{ Indonesia } & frequency & 260 & 579 & 839 \\
\hline & & $\%$ of country & $31.0 \%$ & $69.0 \%$ & $100.0 \%$ \\
\hline & & $\%$ of total & $10.7 \%$ & $23.9 \%$ & $34.6 \%$ \\
\hline & \multirow[t]{4}{*}{ Vietnam } & frequency & 53 & 555 & 608 \\
\hline & & $\%$ of country & $8.7 \%$ & $91.3 \%$ & $100.0 \%$ \\
\hline & & $\%$ of total & $2.2 \%$ & $22.9 \%$ & $25.1 \%$ \\
\hline & & frequency & 660 & 1762 & 2422 \\
\hline & \multirow[t]{2}{*}{ Total } & $\%$ of country & $27.3 \%$ & $72.7 \%$ & $100.0 \%$ \\
\hline & & $\%$ of total & $27.3 \%$ & $72.7 \%$ & $100.0 \%$ \\
\hline
\end{tabular}

Table 6

Length of Chinese Language Learning (All Respondents) $(\chi 2=649.933, d f=3, p .001)$

\begin{tabular}{|c|c|c|c|c|c|c|c|c|}
\hline & & & \multicolumn{5}{|c|}{ How Long Have You Been Learning Chinese? } & \multirow[b]{2}{*}{ Total } \\
\hline & & & $\begin{array}{c}\text { Less } \\
\text { than } 6 \\
\text { Months }\end{array}$ & $\begin{array}{l}6 \text { Months- } \\
1 \text { Year }\end{array}$ & $\begin{array}{c}1-2 \\
\text { Years }\end{array}$ & $\begin{array}{c}2-3 \\
\text { Years }\end{array}$ & $\begin{array}{c}\text { more than } \\
3 \text { Years }\end{array}$ & \\
\hline \multirow[t]{15}{*}{ Country } & Cambodia & frequency & 1 & 8 & 21 & 2 & 595 & 627 \\
\hline & & $\%$ of country & $.2 \%$ & $1.3 \%$ & $3.3 \%$ & $.3 \%$ & $94.9 \%$ & $100.0 \%$ \\
\hline & & $\%$ of total & $.0 \%$ & $.3 \%$ & $.9 \%$ & $.1 \%$ & $24.5 \%$ & $25.8 \%$ \\
\hline & Thailand & frequency & 15 & 59 & 43 & 83 & 165 & 365 \\
\hline & & $\%$ of country & $4.1 \%$ & $16.2 \%$ & $11.8 \%$ & $22.7 \%$ & $45.2 \%$ & $100.0 \%$ \\
\hline & & $\%$ of total & $.6 \%$ & $2.4 \%$ & $1.8 \%$ & $3.4 \%$ & $6.8 \%$ & $15.0 \%$ \\
\hline & Indonesia & frequency & 147 & 62 & 82 & 105 & 439 & 835 \\
\hline & & $\%$ of country & $17.6 \%$ & $7.4 \%$ & $9.8 \%$ & $12.6 \%$ & $52.6 \%$ & $100.0 \%$ \\
\hline & & $\%$ of total & $6.0 \%$ & $2.6 \%$ & $3.4 \%$ & $4.3 \%$ & $18.1 \%$ & $34.3 \%$ \\
\hline & Vietnam & frequency & 185 & 33 & 74 & 42 & 270 & 604 \\
\hline & & $\%$ of country & $30.6 \%$ & $5.5 \%$ & $12.3 \%$ & $7.0 \%$ & $44.7 \%$ & $100.0 \%$ \\
\hline & & $\%$ of total & $7.6 \%$ & $1.4 \%$ & $3.0 \%$ & $1.7 \%$ & $11.1 \%$ & $24.8 \%$ \\
\hline & & frequency & 348 & 162 & 220 & 232 & 1469 & 2431 \\
\hline & Total & $\%$ of country & $14.3 \%$ & $6.7 \%$ & $9.0 \%$ & $9.5 \%$ & $60.4 \%$ & $100.0 \%$ \\
\hline & & $\%$ of total & $14.3 \%$ & $6.7 \%$ & $9.0 \%$ & $9.5 \%$ & $60.4 \%$ & $100.0 \%$ \\
\hline
\end{tabular}


Table 7

"Is Chinese Language Learning Interesting?" $(\chi 2=109.421, d f=3, p<.001)$

\begin{tabular}{|c|c|c|c|c|c|}
\hline & & & Is Chinese Lang & arning Interesting? & \\
\hline & & & Interesting & Not Interesting & Total \\
\hline Country & Cambodia & frequency & 626 & 0 & 626 \\
\hline & & $\%$ of country & $100.0 \%$ & $0.0 \%$ & $100.0 \%$ \\
\hline & & $\%$ of total & $25.7 \%$ & $0.0 \%$ & $25.7 \%$ \\
\hline & Thailand & frequency & 299 & 67 & 366 \\
\hline & & $\%$ of country & $81.7 \%$ & $18.3 \%$ & $100.0 \%$ \\
\hline & & $\%$ of total & $12.3 \%$ & $2.7 \%$ & $15.0 \%$ \\
\hline & Indonesia & frequency & 727 & 112 & 839 \\
\hline & & $\%$ of country & $86.7 \%$ & $13.3 \%$ & $100.0 \%$ \\
\hline & & $\%$ of total & $29.8 \%$ & $4.6 \%$ & $34.4 \%$ \\
\hline & Vietnam & frequency & 520 & 86 & 606 \\
\hline & & $\%$ of country & $85.8 \%$ & $14.2 \%$ & $100.0 \%$ \\
\hline & & $\%$ of total & $21.3 \%$ & $3.5 \%$ & $24.9 \%$ \\
\hline & & frequency & 2172 & 265 & 2437 \\
\hline & tal & $\%$ of country & $89.1 \%$ & $10.9 \%$ & $100.0 \%$ \\
\hline & & $\%$ of total & $89.1 \%$ & $10.9 \%$ & $100.0 \%$ \\
\hline
\end{tabular}

Table 8

"Is Chinese Language Learning Difficult?" $(\chi 2=68.919, d f=3, p<.001)$

\begin{tabular}{|c|c|c|c|c|c|}
\hline & & & \multicolumn{2}{|c|}{ Is Chinese Language Learning Difficult? } & \multirow{2}{*}{ Total } \\
\hline & & & Difficult & Not Difficult & \\
\hline \multirow[t]{15}{*}{ Country } & \multirow[t]{3}{*}{ Cambodia } & frequency & 346 & 277 & 623 \\
\hline & & $\%$ of country & $55.5 \%$ & $44.5 \%$ & $100.0 \%$ \\
\hline & & $\%$ of total & $14.2 \%$ & $11.4 \%$ & $25.6 \%$ \\
\hline & \multirow[t]{3}{*}{ Thailand } & frequency & 294 & 73 & 367 \\
\hline & & $\%$ of country & $80.1 \%$ & $19.9 \%$ & $100.0 \%$ \\
\hline & & $\%$ of total & $12.1 \%$ & $3.0 \%$ & $15.1 \%$ \\
\hline & \multirow[t]{3}{*}{ Indonesia } & frequency & 484 & 349 & 833 \\
\hline & & $\%$ of country & $58.1 \%$ & $41.9 \%$ & $100.0 \%$ \\
\hline & & $\%$ of total & $19.9 \%$ & $14.3 \%$ & $34.2 \%$ \\
\hline & \multirow[t]{4}{*}{ Vietnam } & frequency & 355 & 255 & 610 \\
\hline & & $\%$ of country & $58.2 \%$ & $41.8 \%$ & $100.0 \%$ \\
\hline & & $\%$ of total & $14.6 \%$ & $10.5 \%$ & $25.1 \%$ \\
\hline & & frequency & 1479 & 954 & 2433 \\
\hline & \multirow[t]{2}{*}{ Total } & $\%$ of country & $60.8 \%$ & $39.2 \%$ & $100.0 \%$ \\
\hline & & $\%$ of total & $60.8 \%$ & $39.2 \%$ & $100.0 \%$ \\
\hline
\end{tabular}

It seems that a correlation may be seen between thinking "interesting" and "difficult" in Chinese language learning. It is certain that those who think "difficult" 
feel "not interesting" as shown in all respondents' situation in Table 9.

Table 10 indicates how the Chinese lineage relates to the feeling of difficulty in Chinese language learning by country. Although it is surmised that being a Chinese posterity is a factor letting the student feel Chinese language learning is not difficult, only Thailand looks like an exception in that the Chinese lineage does not affect the perceived difficulty level of Chinese language learning very much.

Table 11 shows the number and ratio of students who feels "difficult" or "not difficult" within three domains of Chinese learning, i.e. pronunciation, grammar, and the writing of characters among those who have studied for more than three years and are considered considerably proficient in the language. As for the relation between a country and difficulties in each of three domains, a statistically significant difference can be found in pronunciation and writing at the $0.1 \%$ level, and in grammar at the $1 \%$ level.

Thai language belongs to Sino-Tibetan language family and is close to Cantonese, and Vietnamese language contains many Chinese origin words because it was influenced by Chinese for thousands of years; however, it belongs to a different language family: Monn- Khmer. These facts come to mind, yet since such confounding factors such as student's attitude and teacher capability are also involved, specifying the causes for this result is not easy.

Table 12 shows which of the three domains of language learning is felt to be difficult correlated with whether the respondents inherit Chinese blood or not. Except for pronunciation, a statistically significant difference is found in grammar and writing at the $0.1 \%$ and $5 \%$ level respectively. While no statistically significant difference was found in grammar and writing by sex, a statistically significant difference was only identified with the result of pronunciation. That is, $61.1 \%$ of the males answered "difficult" and $49.5 \%$ of females answered "difficult" $(\chi 2=31.567$, $\mathrm{df}=1, \mathrm{p}<.001)$.

The reasons to learn the Chinese language. In the questionnaire survey, students were asked what factors influenced their decision to come and learn Chinese (up to three reasons could be chosen). Table 13 shows the results by country.

It turns out that there are many students who have a realistic recognition that "it will probably be useful in the future", if

Table 9

Correlation between Interest and Difficulty $(\chi 2=100.073, d f=1, p<.001)$

\begin{tabular}{|c|c|c|c|c|c|}
\hline & & & \multicolumn{2}{|c|}{ Is Chinese Language Learning Difficult? } & \multirow{2}{*}{ Total } \\
\hline & & & Yes & No & \\
\hline \multirow{6}{*}{$\begin{array}{l}\text { Ethnic } \\
\text { Chinese }\end{array}$} & \multirow[t]{3}{*}{ Yes } & frequency & 1232 & 920 & 2152 \\
\hline & & $\%$ of interesting & $57.2 \%$ & $42.8 \%$ & $100.0 \%$ \\
\hline & & $\%$ of total & $51.1 \%$ & $38.1 \%$ & $89.2 \%$ \\
\hline & \multirow[t]{3}{*}{ No } & frequency & 233 & 28 & 261 \\
\hline & & $\%$ of interesting & $89.3 \%$ & $10.7 \%$ & $100.0 \%$ \\
\hline & & $\%$ of total & $9.7 \%$ & $1.2 \%$ & $10.8 \%$ \\
\hline \multirow{3}{*}{\multicolumn{2}{|c|}{ Total }} & frequency & 1465 & 948 & 2413 \\
\hline & & $\%$ of interesting & $60.7 \%$ & $39.3 \%$ & $100.0 \%$ \\
\hline & & $\%$ of total & $60.7 \%$ & $39.3 \%$ & $100.0 \%$ \\
\hline
\end{tabular}


Table 10

Chinese Language Learning Difficulty Felt by Ethnic Chinese and Not-Ethnic Chinese in 4 Countries $(X 2=258.571, D f=3, P<.001)$

\begin{tabular}{|c|c|c|c|c|c|c|c|c|}
\hline & & & & Cambodia & Thailand & Indonesia & Vietnam & Total \\
\hline \multirow[t]{9}{*}{ Difficult } & \multirow{6}{*}{$\begin{array}{l}\text { Ethnic } \\
\text { Chinese }\end{array}$} & \multirow[t]{3}{*}{ Yes } & Frequency & 294 & 204 & 327 & 106 & 931 \\
\hline & & & $\%$ of ethnic Chinese & $31.6 \%$ & $21.9 \%$ & $35.1 \%$ & $4 \%$ & $100.0 \%$ \\
\hline & & & $\%$ of total & $20.2 \%$ & $14.0 \%$ & $22.5 \%$ & $7.3 \%$ & $64.1 \%$ \\
\hline & & \multirow[t]{3}{*}{ No } & Frequency & 38 & 89 & 156 & 238 & 521 \\
\hline & & & $\%$ of ethnic Chinese & $7.3 \%$ & $17.1 \%$ & $29.9 \%$ & $45.7 \%$ & $100.0 \%$ \\
\hline & & & $\%$ of total & $2.6 \%$ & $6.1 \%$ & $10.7 \%$ & $16.4 \%$ & $35.9 \%$ \\
\hline & \multirow{3}{*}{\multicolumn{2}{|c|}{ Total }} & Frequency & 332 & 293 & 483 & 344 & 1452 \\
\hline & & & $\%$ of ethnic Chinese & $22.9 \%$ & $20.2 \%$ & $33.3 \%$ & $23.7 \%$ & $100.0 \%$ \\
\hline & & & $\%$ of total & $22.9 \%$ & $20.2 \%$ & $33.3 \%$ & $23.7 \%$ & $100.0 \%$ \\
\hline \multirow{9}{*}{$\begin{array}{l}\text { Not } \\
\text { Difficult }\end{array}$} & \multirow{6}{*}{$\begin{array}{l}\text { Ethnic } \\
\text { Chinese }\end{array}$} & \multirow[t]{3}{*}{ Yes } & Frequency & 248 & 50 & 221 & 150 & 669 \\
\hline & & & $\%$ of ethnic Chinese & $37.1 \%$ & $7.5 \%$ & $33.0 \%$ & $22.4 \%$ & $100.0 \%$ \\
\hline & & & $\%$ of total & $26.4 \%$ & $5.3 \%$ & $23.5 \%$ & $15.9 \%$ & $71.1 \%$ \\
\hline & & \multirow[t]{3}{*}{ No } & Frequency & 25 & 23 & 124 & 100 & 272 \\
\hline & & & $\%$ of ethnic Chinese & $9.2 \%$ & $8.5 \%$ & $45.6 \%$ & $36.8 \%$ & $100.0 \%$ \\
\hline & & & $\%$ of total & $2.7 \%$ & $2.4 \%$ & $13.2 \%$ & $10.6 \%$ & $28.9 \%$ \\
\hline & \multirow{3}{*}{\multicolumn{2}{|c|}{ Total }} & Frequency & 273 & 73 & 345 & 250 & 941 \\
\hline & & & $\%$ of ethnic Chinese & $29.0 \%$ & $7.8 \%$ & $36.7 \%$ & $26.6 \%$ & $100.0 \%$ \\
\hline & & & $\%$ of total & $29.0 \%$ & $7.8 \%$ & $36.7 \%$ & $26.6 \%$ & $100.0 \%$ \\
\hline \multirow[t]{9}{*}{ Total } & \multirow{6}{*}{$\begin{array}{l}\text { Ethnic } \\
\text { Chinese }\end{array}$} & \multirow[t]{3}{*}{ Yes } & Frequency & 542 & 254 & 548 & 256 & 1600 \\
\hline & & & $\%$ of ethnic Chinese & $33.9 \%$ & $15.9 \%$ & $34.3 \%$ & $16.0 \%$ & $100.0 \%$ \\
\hline & & & $\%$ of total & $22.6 \%$ & $10.6 \%$ & $22.9 \%$ & $10.7 \%$ & $66.9 \%$ \\
\hline & & \multirow[t]{3}{*}{ No } & Frequency & 63 & 112 & 280 & 338 & 793 \\
\hline & & & $\%$ of ethnic Chinese & $7.9 \%$ & $14.1 \%$ & $35.3 \%$ & $42.6 \%$ & $100.0 \%$ \\
\hline & & & $\%$ of total & $2.6 \%$ & $4.7 \%$ & $11.7 \%$ & $14.1 \%$ & $33.1 \%$ \\
\hline & \multirow{3}{*}{\multicolumn{2}{|c|}{ Total }} & Frequency & 605 & 366 & 828 & 594 & 2393 \\
\hline & & & $\%$ of ethnic Chinese & $25.3 \%$ & $15.3 \%$ & $34.6 \%$ & $24.8 \%$ & $100.0 \%$ \\
\hline & & & $\%$ of total & $25.3 \%$ & $15.3 \%$ & $34.6 \%$ & $24.8 \%$ & $100.0 \%$ \\
\hline
\end{tabular}

they learn Chinese. It is also backed up by the recognition that the "Chinese language is an international language on a par with English", and these two reasons were almost equally valued. There were some students who wrote "Chinese language will turn into an international language in the future since China is a country developing very quickly" (Cambodia, grade 1 of high school, a male), and "Because there are many opportunities to get a scholarship and a job if we study the Chinese language (except for English)" (Vietnam, grade 1 of high school, a female) in the free description column. In addition to these, about 30 percent of respondents chose "having been interested from the beginning" even if vaguely and "being interested in Chinese culture and history" and as a means to understand Chinese cultural more deeply. Moreover, those who answered that it is because it was "recommended by parents" also accounted 
Yutaka Otsuka: Chinese Language Learning ...

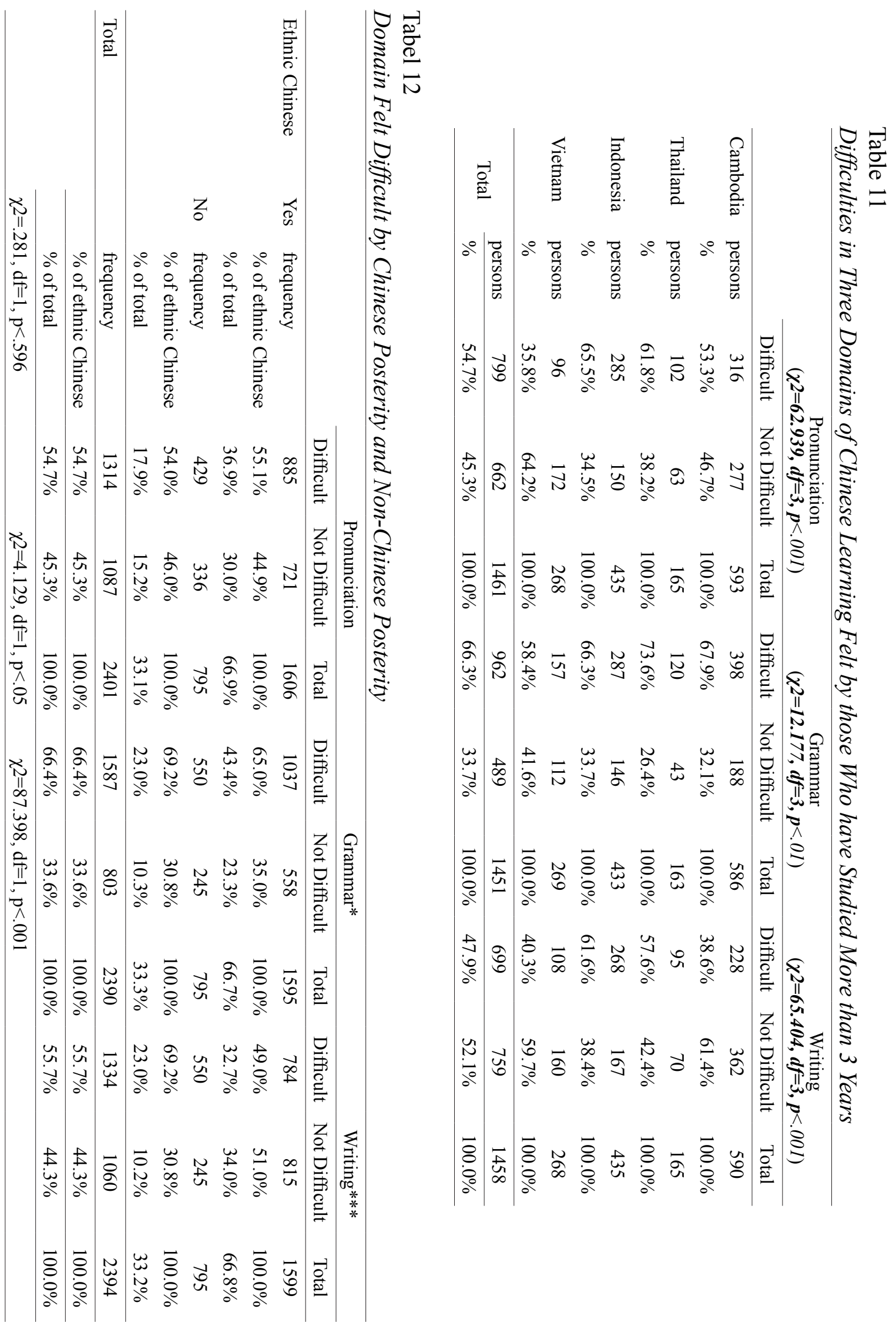


Table 13

Reasons to have Chosen Chinese Language Learning (All Respondents)

\begin{tabular}{|c|c|c|c|c|c|c|c|}
\hline & & $\begin{array}{l}\text { Useful } \\
\text { in the } \\
\text { Future }\end{array}$ & $\begin{array}{l}\text { Interested } \\
\text { from the } \\
\text { Beginning }\end{array}$ & $\begin{array}{c}\text { Interest in } \\
\text { Chinese } \\
\text { Culture \& } \\
\text { History }\end{array}$ & $\begin{array}{c}\text { Inter- } \\
\text { national } \\
\text { Language }\end{array}$ & $\begin{array}{c}\text { Persuaded } \\
\text { by } \\
\text { Parents }\end{array}$ & $\begin{array}{c}\text { Friends } \\
\text { Chose to } \\
\text { Study }\end{array}$ \\
\hline \multirow[t]{3}{*}{ Cambodia } & frequency & 587 & 273 & 311 & 511 & 106 & 15 \\
\hline & $\%$ of country & $93.0 \%$ & $43.3 \%$ & $49.3 \%$ & $81.0 \%$ & $16.8 \%$ & $2.4 \%$ \\
\hline & $\%$ of total & $23.9 \%$ & $11.1 \%$ & $12.7 \%$ & $20.8 \%$ & $4.3 \%$ & $0.6 \%$ \\
\hline \multirow[t]{3}{*}{ Thailand } & frequency & 270 & 116 & 62 & 265 & 170 & 40 \\
\hline & $\%$ of country & $73.6 \%$ & $31.6 \%$ & $16.9 \%$ & $72.2 \%$ & $46.3 \%$ & $10.9 \%$ \\
\hline & $\%$ of total & $11.0 \%$ & $4.7 \%$ & $2.5 \%$ & $10.8 \%$ & $6.9 \%$ & $1.6 \%$ \\
\hline \multirow[t]{3}{*}{ Indonesia } & frequency & 436 & 201 & 153 & 389 & 190 & 34 \\
\hline & $\%$ of country & $51.7 \%$ & $18.1 \%$ & $18.1 \%$ & $46.10 \%$ & $22.5 \%$ & $1.0 \%$ \\
\hline & $\%$ of total & $17.70 \%$ & $6.2 \%$ & $6.2 \%$ & $15.80 \%$ & $7.7 \%$ & $1.4 \%$ \\
\hline \multirow[t]{3}{*}{ Vietnam } & frequency & $286 \%$ & 223 & 212 & 402 & 275 & 76 \\
\hline & $\%$ of country & $46.4 \%$ & $36.1 \%$ & $34.4 \%$ & $65.2 \%$ & $44.6 \%$ & $12.3 \%$ \\
\hline & $\%$ of total & $11.6 \%$ & $9.1 \%$ & $8.6 \%$ & $16.4 \%$ & $11.2 \%$ & $3.1 \%$ \\
\hline \multirow[t]{3}{*}{ Total } & frequency & 1579 & 813 & 738 & 1567 & 741 & 165 \\
\hline & $\%$ of country & $64.2 \%$ & $33.1 \%$ & $30.0 \%$ & $63.8 \%$ & $30.1 \%$ & $6.7 \%$ \\
\hline & $\%$ of total & $64.2 \%$ & $33.1 \%$ & $30.0 \%$ & $63.8 \%$ & $30.1 \%$ & $6.7 \%$ \\
\hline
\end{tabular}

for 30 percent. There are few who chose a passive reason like "because friends chose to study Chinese language", and thus almost all of the respondents are learning the Chinese language for positive reasons. Some students wrote "because I like a Chinese music group" (Vietnam, grade 1 of high school, female), and "because I was assigned to the Chinese class as a result of the entrance examination" (Vietnam, grade 3 of high school, female) in the free description column. Judging from the free description, those with good academic performance seem to be assigned to an English class in Vietnam.

Looking at the reply about the reasons to learn Chinese language by sex, only those who chose the reason "Having been interested from the beginning" $(27.0 \%$ for males, $37.7 \%$ for females) has a statistically significant difference $\left(\chi^{2}=30.619, d f=1\right.$, $p<.001)$. Next, Table 14 shows the reasons to learn the Chinese language only for the ethnic Chinese.

Chinese posterity in Cambodia and Thailand has shown an especially high ratio of those who chose to learn Chinese language based upon a practical viewpoint such as "it will be helpful in the future" and "since it is an international language." On the other hand, Chinese posterity in Thailand and Vietnam has shown a high ratio of those who chose "because it was recommended by parents", and especially Chinese posterity in Vietnam is about twenty percent higher than the response given by others regardless of Chinese posterity or non-Chinese posterity of the country.

This is also statistically significant and could be explained as dedication to the Chinese language of the parental 
Table 14

Reasons for Having Chosen the Chinese Language among the Chinese Posterity Only by Country $(\mathrm{X} 2=221.617, D f=3, P<.001)$

\begin{tabular}{|c|c|c|c|c|c|c|c|}
\hline & & $\begin{array}{l}\text { Useful } \\
\text { in the } \\
\text { Future }\end{array}$ & $\begin{array}{l}\text { Interested } \\
\text { from the } \\
\text { Beginning }\end{array}$ & $\begin{array}{c}\text { Interest in } \\
\text { Chinese } \\
\text { Culture \& } \\
\text { History }\end{array}$ & $\begin{array}{c}\text { Inter- } \\
\text { national } \\
\text { Language }\end{array}$ & $\begin{array}{c}\text { Persuaded } \\
\text { by } \\
\text { Parents }\end{array}$ & $\begin{array}{c}\text { Friends } \\
\text { Chose to } \\
\text { Study }\end{array}$ \\
\hline \multirow[t]{3}{*}{ Cambodia } & frequency & 514 & 245 & 271 & 442 & 85 & 11 \\
\hline & $\%$ of country & $93.6 \%$ & $44.6 \%$ & $49.4 \%$ & $80.5 \%$ & $15.5 \%$ & $2.0 \%$ \\
\hline & $\%$ of total & $31.9 \%$ & $15.2 \%$ & $16.8 \%$ & $27.4 \%$ & $5.3 \%$ & $0.7 \%$ \\
\hline \multirow[t]{3}{*}{ Thailand } & frequency & 183 & 76 & 47 & 183 & 129 & 26 \\
\hline & $\%$ of country & $72.0 \%$ & $29.9 \%$ & $18.5 \%$ & $72.0 \%$ & $50.8 \%$ & $10.2 \%$ \\
\hline & $\%$ of total & $11.4 \%$ & $4.7 \%$ & $2.9 \%$ & $11.4 \%$ & $8.0 \%$ & $1.6 \%$ \\
\hline \multirow[t]{3}{*}{ Indonesia } & frequency & 279 & 108 & 103 & 248 & 167 & 29 \\
\hline & $\%$ of country & $50.5 \%$ & $19.6 \%$ & $18.7 \%$ & $44.9 \%$ & $30.3 \%$ & $5.3 \%$ \\
\hline & $\%$ of total & $17.3 \%$ & $6.7 \%$ & $6.4 \%$ & $15.4 \%$ & $10.4 \%$ & $1.8 \%$ \\
\hline \multirow[t]{3}{*}{ Vietnam } & frequency & 122 & 81 & 81 & 142 & 164 & 47 \\
\hline & $\%$ of country & $47.5 \%$ & $31.5 \%$ & $31.5 \%$ & $55.3 \%$ & $63.8 \%$ & $18.3 \%$ \\
\hline & $\%$ of total & $7.6 \%$ & $5.0 \%$ & $5.0 \%$ & $8.8 \%$ & $10.2 \%$ & $2.9 \%$ \\
\hline \multirow[t]{3}{*}{ Total } & frequency & 1098 & 502 & 502 & 1015 & 545 & 113 \\
\hline & $\%$ of country & $68.1 \%$ & $31.1 \%$ & $31.1 \%$ & $63.0 \%$ & $33.8 \%$ & $7.0 \%$ \\
\hline & $\%$ of total & $68.1 \%$ & $31.1 \%$ & $31.1 \%$ & $63.0 \%$ & $33.8 \%$ & $7.0 \%$ \\
\hline
\end{tabular}

generation. Some students wrote "My parents have advised me to study the Chinese language which is the ancestral language, since all families are ethnic Chinese" (Vietnam, grade 1 of junior high school, female), "I am an ethnic Chinese and my parents persuaded me to study the Chinese language" (Vietnam, grade 4 of junior high school, male), "My purpose is to study Japanese in the future. Since the Chinese language and Japanese are akin, if the Chinese language is studied firmly, it will be useful for studying Japanese in the future" (Vietnam, grade 4 of junior high school, male) in the free description column.

The wish for studying-abroad. To the question, "Do you want to study in China (not only in the Mainland but in Hong Kong or Taiwan) in the future, if there is an opportunity?", as shown in Table 15, those who answered "Yes" were 75.2 percent, which is three times more than those who answered "No" at $24.8 \%$.

The ratio of those with Chinese posterity wishing to study abroad is almost the same as the number without Chinese posterity. In addition, looking at the difference by sex, 69.3 percent of males and 79.1 percent of females answered "I would like to study abroad", females are more positive, and a statistically significant difference was found $(\chi 2=29.964, d f=1$, $p<.001$ ).

A wish to study abroad may also change with the length of time spent learning the Chinese language. Among those who have just begun to study the Chinese language, there are many (80 percent or more) hoping to study abroad as 
Table 15

Difference of Wish for Studying-Abroad between Chinese Posterity and Non-Chinese Posterity $\left(\chi^{2}=16.615, d f=1, p<.001\right)$

\begin{tabular}{|c|c|c|c|c|c|}
\hline & & & \multicolumn{2}{|c|}{ Wish for Studying Abroad } & \multirow{2}{*}{ Total } \\
\hline & & & Yes & No & \\
\hline \multirow{6}{*}{$\begin{array}{l}\text { Ethnic } \\
\text { Chinese }\end{array}$} & Yes & frequency & 1228 & 352 & 1580 \\
\hline & & $\%$ of Chinese posterity & $77.7 \%$ & $22.3 \%$ & $100.0 \%$ \\
\hline & & $\%$ of total & $51.7 \%$ & $14.8 \%$ & $66.5 \%$ \\
\hline & No & frequency & 557 & 238 & 795 \\
\hline & & $\%$ of Chinese posterity & $70.1 \%$ & $29.9 \%$ & $100.0 \%$ \\
\hline & & $\%$ of total & $23.5 \%$ & $10.0 \%$ & $33.5 \%$ \\
\hline \multirow[t]{3}{*}{ Total } & & frequency & 1785 & 590 & 2375 \\
\hline & & $\%$ of Chinese posterity & $75.2 \%$ & $24.8 \%$ & $100.0 \%$ \\
\hline & & $\%$ of total & $75.2 \%$ & $24.8 \%$ & $100.0 \%$ \\
\hline
\end{tabular}

shown in Fig. 1. However, while continuing to study, it is surmised that an awareness of the difficulties of the Chinese language increases; therefore, the ratio of those wishing to study abroad falls gradually as mentioned above. However, those who have learned for three years or more, unlike the beginners, can feel confident about language acquisition and increasingly wish to study abroad. The difference by country can be seen here.

As shown in Table 16, compared with the three other countries, those wishing to study abroad in Vietnam account for 59.6 percent which is 30 percent less than Cambodia and 15 percent less than the average of the four countries.

Fig. 1. Change of Hope for Studying Abroad by the Length of Learning of Chinese Language

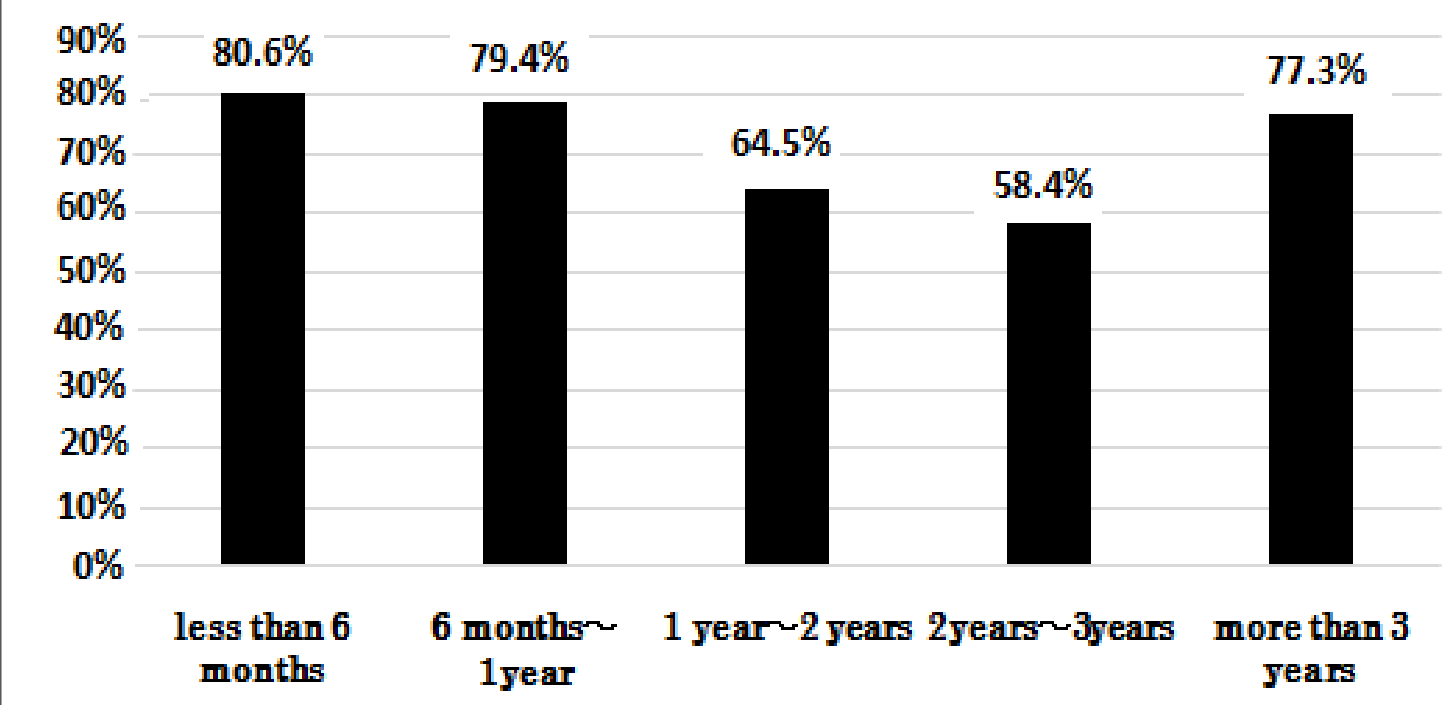


Table 16

Wish for Studying Abroad in the Chinese Speaking World $(\chi 2=151.853, \mathrm{df}=3, \mathrm{p}<.001)$

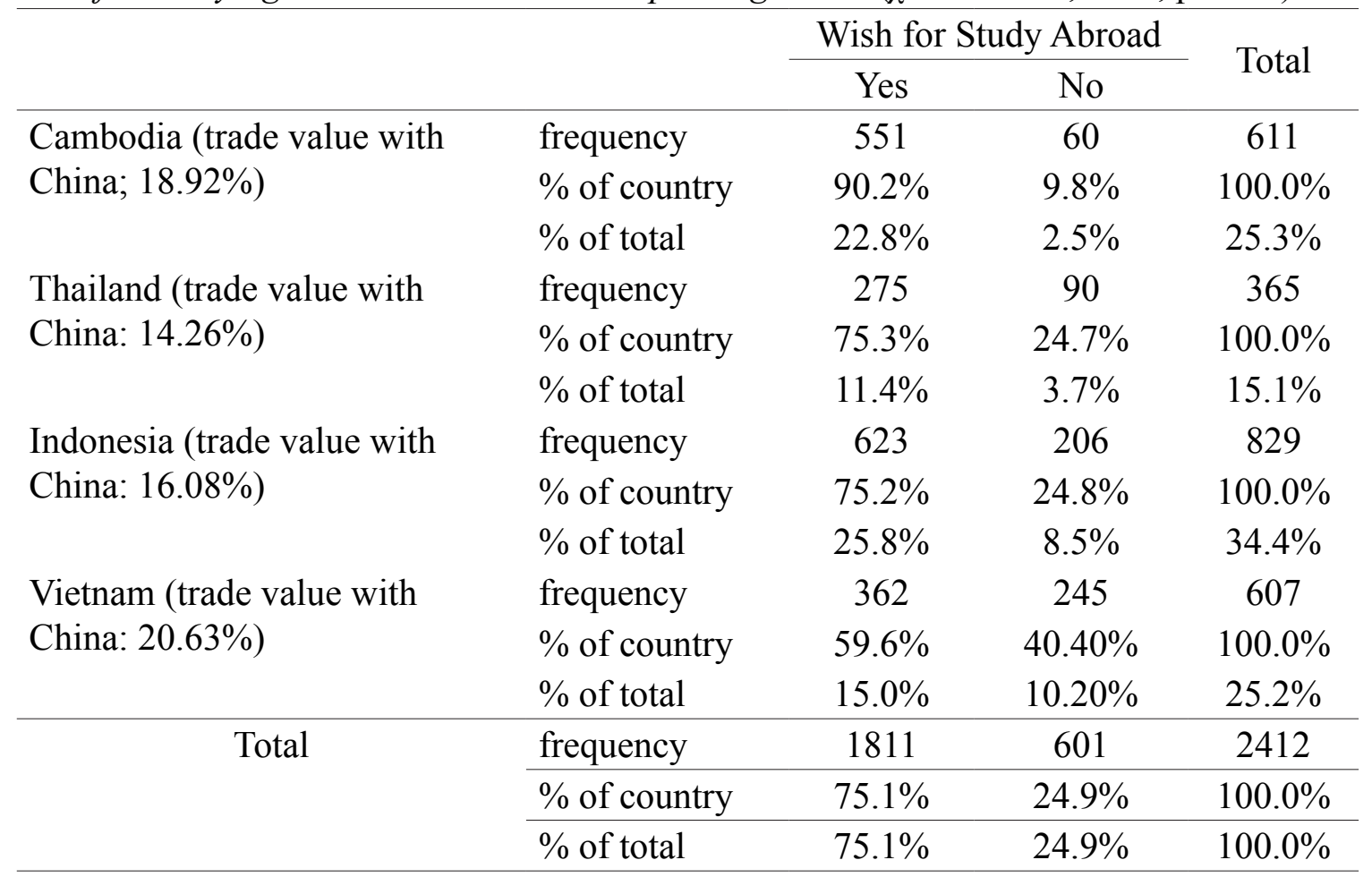

If there is a favorability rating survey of interest in countries such as the Country Rating Poll carried out by the British Broadcasting Corporation (BBC), it would be convenient, but the BBC's survey does not cover all of the four investigated countries. Therefore, using each country's trade rate with China (the ratio of the trade value with China in each country's total amount of imports and exports) as a substitution, an inversion phenomenon can be found. That is, Vietnam, with the highest trade rate with China and being considered to enjoy fairly intimate relations, is the contrary ranked the lowest in terms of the ratio of students who wish to study in China. On the other hand, Vietnam, which has highest ratio of students who began Chinese language learning because they were persuaded by their parents, is lower. In ancient times, while obeying China as a tributary state,
Vietnam used to adhere strongly to China's cultural influences including the Chinese higher civil service examination.

Moreover, an extraordinarily number of Vietnamese students were accepted by and went to China as foreign students during the Vietnam War (Cengjiu, 1984, p. 136). This is despite the fact that, at that time there existed problems between the two countries including the ChinaVietnamese War (1979) and a dominium issue involving the Spratly Islands, etc. In such a love-and-hate relationship, it is not easy to interpret underlying motivations and disincentives toward studying abroad in China.

Of the four countries concerned, Thailand started to establish the Confucius Institute in 2006 and already has 12 locations. Cambodia established one in 2009, and Indonesia established 6 in 2010. 
These countries are quite positive to accept the Confucius Institute and established it quite early. On the other hand, Vietnam was slow to move. The establishment of the Confucius Institute was discussed at the time Chinese Prime Minister Li Keqiqiang visited Vietnam in October 2013. It was decided to establish one at Hanoi university at last, but it took a while for its management to get off the ground. Although Vietnam is the top of the four nations in terms of the trade volume, it was considerably more careful about accepting Chinese language or the Chinese culture. It can be said that Vietnam's feelings toward China as the whole country appears to be mirrored in the results of students' wish to study abroad in China.

\section{CONCLUSION}

So far, the history of overseas Chinese and ethnic Chinese along with Chinese language education in four southeast Asian countries was overviewed, and then what kind of awareness students have toward Chinese language and Chinese language education after various episodes of oppression, followed by the subsequent repealing of the ban on using the Chinese language was analyzed. I would like to conclude by summarizing the points which became clear through the analysis.

First of all, the enthusiastic rise of Chinese language learning has been widely found not only among Chinese posterity but also among non-ethnic Chinese students in each of the four nations. Among them, the concern about the Chinese language and the strong consciousness of its usefulness was observed through the responses to the questionnaire questions. Those who mentioned its international nature and practicality as a reason for learning Chinese language accounted for 60 percent or more. In addition, 88.9 percent of all respondents are studying English in addition to the Chinese language in school.

Secondly, those who considered the study of the Chinese language "interesting" account for about 90 percent. There is almost no difference between Chinese posterity and non-Chinese posterity. On the other hand, with regard to the feeling of difficulty, non-Chinese posterity reported that the study of the Chinese language feels more "difficult." Those who feel the Chinese language learning to be "difficult" are 58.2 percent of Chinese posterity, and 65.7 percent of non-Chinese posterity as a whole, but in Thailand the ratio of those who feel it to be "difficult" accounts for 80.1 percent as a whole and recaches as high as 80.3 percent among Chinese posterity.

Thirdly, 57.3 percent answered in the affirmative, and 42.7 percent in the negative to the question "Is there any person daily using Chinese language in your home or among your relatives?" Within the Chinese posterity group, some respondents reported daily use of the Chinese language in three fourth of the respondents' families. In the case of Chinese posterity, frequent chances to encounter the Chinese language at home facilitated learning of the language. However, only in Vietnam is the situation reversed with 35.0 percent of respondents affirming, and 65.0 percent denying daily usage of the Chinese language at home.

Fourthly, analyzing the correlation between thinking that the study of the Chinese language is "interesting" and that it is "difficult" and then extending this analysis to include which aspect of the language (pronunciation, grammar, or writing) is felt to be "difficult" in the light of difference of country and difference of Chinese posterity and non-Chinese posterity, revealed a statistically significant difference with writing exemplifying a typical case. It seems possible to interpret 
the fact based upon the linguistic-proximity or congeniality of between the Chinese language and each of the other languages.

Fifthly, about studying abroad in Chinese-speaking areas, 75.2 percent answered positively, and 24.8 percent answered negatively, that is, there are three times more students in favor. However, in the case of Vietnam, the result was 15 percent lower than the average. This is despite Vietnam having the highest level of trade with China of the four countries. Complicated emotions can be imagined in the background that has been developed in the long history. It is also apparent in the relative shortness of time in which the learning of the Chinese language has taken place there.

\section{Acknowledgement}

This work was supported by JSPS (Japan Society for the Promotion of Science) KAKENHI Gant Number JP18K02430.

\section{REFERENCES}

Cengjiu, Z. J. (1984). Educational Achievement: Statistical yearbook 1949-1983. China: People's Educational Publisher.

Guwen, Y. J. P. H. J. (2001). The Indonesian Ministry of Education invited Chinese language educational advisers. Huasheng Bao Newspaper. Retrieved from http://edu.sina.com.cn/s/19940. shtml.

Hiizumi, K. (1987). Tai ni okeru kakyo bunka no ittan: Kyoko, kago, kaho" (Some aspects of overseas Chinese culture in Thailand: Overseas Chinese school, Chinese language, and Chinese language newspaper). Jinbun Gakubu Kiyo (Bulletin of Faculty of Humanities), 22, 129-130.

Huntington, S. (2000). Bunmei no shototsu to 21 seiki no nihon (Clash of civilizations and the $21^{\text {st }}$ century Japan). Tokyo: Shuisha.

Joshua Project. (n.d). Retrieved from http:// joshuaproject.net/countries/CB.

Murata, Y. (2007). Tai ni okeru kyoiku hatten; Kokumin togo, bunka, kyoiku kyoryoku (Educational development in Thailand; National unity, culture, and educational cooperation). Tokyo: Toshindo Publishing.

Otsuka, Y. (2008). Vietnam shoto kyoiku no fuhenka to saika: kajin no tameno kago kyoiku o megutte" (Universalization and Differentiation of Elementary Education in Vietnam: Chinese language education for the ethnic Chinese). In Ushiogi, M. (Eds.), Vietnam ni okeru shoto kyoiku no fuhenka seisaku (Universalization policy of elementary school education in Vietnam) (pp. 127-145). Tokyo: Akashi Shoten.

Otsuka, Y. (2015). Chinese language education in Indonesian local cities). Daigaku Kyoiku Ronso (Bulletin of University Education Center), 1, 49-65. Saigon Liberation Daily. (2020).

Suzuki, K. (1995). Tai ni okeru kajinkei gakko seisaku no doko: Kisei kanwa sochi no kento o chusin toshite" (Trends of the Policy on Ethnic Chinese Schools in Thailand: Centering on the analysis of deregulation measures. Hikaku Kokusai Kyoiku (Comparative and International Education), 3, 8889.

Tamaki, M. (2007). Tai shakai ni okeru kago kyoiku no genjo (present situation of Chinese language education in ethnic Chinese society in Thailand) Overseas Chinese Research Center of Takushoku University. Newsletter, 4. Retrieved from http://www.cocs. takushoku-u.ac.jp/nl4/1.htm. 
Top ten languages used in the web. (n.d). Retrieved from http://www. internetworldstats.com/stats7.htm.

Weineng, G., \& Xiaohong, W. (2003). Dongnanya huawen jiaoyu fazhan; Dongnanya huaren qingkuang 2002 nian huigu yu 2003 qianzhan zhi er" (Development of Chinese language education in Southeast Asia: Situation of ethnic Chinese people in Southeast Asia, retrospect of 2002 and foresight of 2003). Dongnanya Zongheng (Encompassing Southeast Asia), 6. Retrieved from http://mall.cnki.net/ magazine/Article/DLYZ200306008. htm.
Yannan, C. (2005). Indonesia kajin to sono shakaiteki chii" (Ethnic Chinese People in Indonesia and their Economic Position) Overseas Chinese Research Center of Takushoku University). Newsletter, 4. Retrieved from http://www.cocs. takushoku-u.ac.jp/nl4/1.htm.

Yu-e, Z. (1995). Dongnanya huawen jiaoyu (Chinese Education in Southeast Asia). Jinan: University Press.

Yu-e, Z., \& Lei, C. (n.d). Zhuanbian zhong de Yinni Huawen Jiaoyu" (Chinese language education in transition in Indonesia. Retrieved from http://edu. sina.com.cn/s/19940.shtml. 